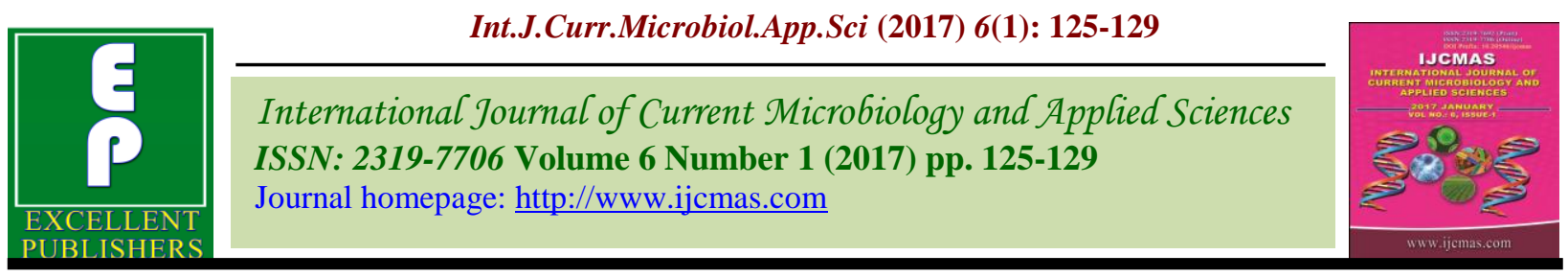

Review Article

http://dx.doi.org/10.20546/ijcmas.2017.601.016

\title{
Role of Phytoalexins in Plant Disease Resistance
}

\author{
Roop Singh $^{1 *}$ and Kuldeep Singh Chandrawat ${ }^{2}$ \\ ${ }^{1}$ Department of Plant Pathology, Rajasthan College of Agriculture, \\ MPUAT, Udaipur (RAJ) 313001, India \\ ${ }^{2}$ Department of Plant Breeding and Genetics, Rajasthan College of Agriculture, \\ MPUAT, Udaipur (RAJ) 313001, India \\ *Corresponding author
}

A B S T R A C T

Keywords

Phytoalexins,

Plant Disease, de novo synthesis

Article Info

Accepted:

12 December 2016

Available Online:

10 January 2017
Phytoalexins are low molecular weight antimicrobial compounds that are produced by plants as a response to biotic and abiotic stresses. The rapidity and extent of their accumulation is determined by their release of immediate precursors from conjugates or de novo synthesis, as well as detoxification as a result of plant or microbial enzymes. The rapidity of phytoalexin accumulation is associated with resistance in plants to diseases caused by fungi and bacteria, although the genetic information for phytoalexin synthesis is found in susceptible and resistant plants. Phytoalexins are only one component of the complex mechanisms for disease resistance in plants.

\section{Introduction}

Antimicrobial compounds from plants are broadly classified into two categories: phytoantipicins and phytoalexins (Mansfield, 1999). Phytoanticipins; Phytoanticipins are described as "low molecular weight, antimicrobial compounds that are present in plants before challenge by micro-organisms, or are produced after infection solely, from pre-existing precursors". They include primarily the saponins, avenacin and tomatine. One saponin, avenacin A-1, is localized in the epidermis of oat roots and another saponin, a-tomatine, is produced in tomato and has antimicrobial activity against many fungi. Phytoalexins; Phytoalexins are toxic antimicrobial substances produced in appreciable amounts in plants only after stimulation by various types of phytopathogenic microorganisms or by chemical and mechanical injury. It was proposed in 1940 by Muller and Borger in the study of the interaction between potato and Phytophthora infestans. Most known phytoalexins are toxic to and inhibit the growth of fungi pathogenic to plants, but some are also toxic to bacteria, nematodes, and other organisms. More than 350 phytoalexins have been chemically characterized from approximately 30 plant families. The greatest number 130 have been characterized from the Leguminosae (Joseph, 1995). The chemical structures of 
phytoalexins produced by plants of a family are usually quite similar; e.g., in most legumes, phytoalexins are is oflavonoids, and in the Solanaceae they are terpenoids. Phytoalexins represents one component of a battery of induced defence mechanisms used by plants including lytic enzymes such as chitinases and glucanases, oxidizing agents, cell wall lignifications and a number of pathogenesis-related (PR) proteins and transcripts of unknown functions (Dixon and Lamb, 1990; Lamb et al.,, 1989). It is important to recognize that phytoalexin accumulation may be part of a co-ordinated defence strategy, in which any one factor may alone be unable to account for restriction of the potential pathogen (Mansfield, 1999).

\section{Chemical Diversity of Phytoalexins}

Most phytoalexins produced by the Leguminosae belong to six isoflavonoid classes: isoflavones, isoflavanones, pterocarpans, pterocarpenes, isoflavans and coumestans (Table 1). Some pterocarpan phytoalexins are especially well known: pisatin, phaseollin, glyceollin, medicarpin and maackiain. Pisatin was the first phytoalexin to be isolated and characterized from garden pea, Pisum sativum (Cruickshank and Perrin 1960). Besides these compounds, a small number of legumes also produce non-isoflavonoid phytoalexins such as furanoacetylenes and stilbenes (Table 1).

\section{Elicitors of phytoalexin accumulation}

The molecules that signal plants to begin the process of phytoalexin synthesis are called elicitors. Elicitors of biotic origin may be involved in the interaction of plants and potential pathogens, whereas abiotic elicitors are not involved in normal host-pathogen interactions (Darvill and Albersheim, 1984).

In natural conditions, the stimulus is provided by the presence of the micro-organism and its perception by the host initiates the chain of events leading to phytoalexin synthesis. Biotic elicitors may originate in the invading organism, in which case they are referred to as "exogenous", whereas "endogenous" elicitors are of plant origin and are generated by the interaction between micro-organism and plant. Molecules with elicitor activity have been identified across a wide range of structural types including polysaccharides, glycoproteins, lipids, lipopolysaccharides, oligosaccharides and even enzymes, though their activity can be attributed to their effect in releasing elicitor-active components from the cell walls of the pathogen or host (Anderson, 1989; Blein et al.,,1991; Alghisi and Favaron, 1995). Abiotic elicitors form a diverse collection of molecules that are not derived from natural sources, such as the tissues of the pathogen or host. Under normal circumstances, they would not be encountered by the plant. The group includes compounds such as fungicides; salts of heavy metals, for example $\mathrm{Cu} 2+$ and $\mathrm{Hg} 2+$; the detergents, basic molecules such as polylysine and histone; reagents that are intercalated DNA (Darvill and Albersheim, 1984). Treatment of plant tissues with factors that cause stress, for example repeated freezing and thawing, wounding or exposure to UV light (Kodama et al., 1992; Mert Turk et al., 1998) can also induce phytoalexin synthesis.

\section{Phytoalexin in disease resistance}

Phytoalexins accumulate at infection sites and they inhibit the growth of fungi and bacteria in vitro therefore, it is logical to consider them as possible plant-defence compounds against diseases caused by fungi and bacteria. Phytoalexins are considerably less toxic than chemical fungicides. Phytoalexin fungitoxicity is clearly evidenced by the inhibition of germ-tube elongation, radial mycelial growth and mycelia dry weight increase, as best illustrated by the 
action of resveratrol on B. cinerea, the causal agent for gray mold in grapevine. Phytoalexins may also exert some effects on the cytological, morphological and physiological characteristics of fungal cells. The activity of four phytoalexins from the Solanaceae family (rishitin, phytuberin, anhydro- $\beta$-rotunol and solavetivone) on three Phytophthora species resulted in loss of motility of the zoospores, rounding-up of the cells associated with some level of swelling, cytoplasmic granulation and bursting of the cell membrane (Harris and Dannis, 1997).

Table.1 Phytoalexins from different plant families

\begin{tabular}{|c|l|l|}
\hline S. No. & \multicolumn{1}{|c|}{ Plant Families } & \multicolumn{1}{c|}{ Types of Phytoalexins } \\
\hline 1. & Amaryllidaceae & Flavans \\
\hline 2. & Brassicaceae & $\begin{array}{l}\text { Indole phytoalexins/camalexin } \\
\text { Sulfur-containing phytoalexins/brassinin }\end{array}$ \\
\hline 3. & Chenopodiaceae & Flavanones/betagarin Isoflavones/betavulgarin \\
\hline 4. & Compositae & Polyacetylenes/safynol \\
\hline 5. & Convolvulaceae & Furanosesquiterpenes/Ipomeamarone \\
\hline 6. & Euphorbiaceae & Diterpenes/casbene \\
\hline 7. & Poaceae & $\begin{array}{l}\text { Diterpenoids: Momilactones; Oryzalexins; Zealexins; } \\
\text { Phytocassanes; Kauralexins } \\
\text { Deoxyanthocyanidins/luteolinidin and apigeninidin } \\
\text { Flavanones/sakuranetin } \\
\text { Phenylamides }\end{array}$ \\
\hline 8. & Leguminosae & $\begin{array}{l}\text { Isoflavones, Isoflavanones, Isoflavans, Coumestans } \\
\text { Pterocarpans/pisatin, phaseollin, glyceollin and maiackiain } \\
\text { Furanoacetylenes/wyerone Stilbenes/resveratrol Pterocarpens }\end{array}$ \\
\hline 9. & Linaceae & Phenylpropanoids/coniferyl alcohol \\
\hline 10. & Malvaceae & Terpenoids naphtaldehydes/gossypol \\
\hline 11. & Moraceae & Furanopterocarpans/moracins A-H \\
\hline 12. & Orchidaceae & Dihydrophenanthrenes/loroglossol \\
\hline 13. & Rutaceae & Methylated phenolic compounds/xanthoxylin \\
\hline 14. & Umbelliferae & $\begin{array}{l}\text { Polyacetylenes/falcarinol } \\
\text { Phenolics: xanthotoxin } \\
\text { 6-methoxymellein }\end{array}$ \\
\hline 15. & Vitaceae & Stilbenes/resveratrol \\
\hline 16. & Rosaceae & $\begin{array}{l}\text { Biphenyls/auarperin } \\
\text { Dibenzofurans/cotonefurans }\end{array}$ \\
\hline 17. & Solanaceae & $\begin{array}{l}\text { Phenylpropanoid related compounds } \\
\text { Steroid glycoalkaloids } \\
\text { Norsequi and sesquiterpenoids } \\
\text { Coumarins } \\
\text { Polyacetylenic derivatives }\end{array}$ \\
\hline
\end{tabular}


Concerning the accumulation of pisatin in pea and phaseollin in green bean, it was apparent that the phytoalexins accumulated to fungitoxic concentrations not only in inoculum droplets placed on opened pea or bean pods but also in the tissues immediately below the inoculum droplets (Cruickshank and Perrin, 1968). Asymetric growth of the germ tube resulting in the production of "curved-germ tubes" has also been observed in $B$. cinerea conidia treated with sub-lethal doses of resveratrol. This cytological abnormality suggests that stilbenic compounds may interact with tubulin polymerization, the mode of action of many synthetic fungicides and anticancer agents (woods et al., 1995). Moreover, phytoalexins may affect glucose uptake by fungal cells as reported in the interactions between phaseollin or kievitone and Rhizoctonia solani. Conidia of $B$. cinerea showed a complete disorganization of mitochondria and disruption of the plasma membrane upon treatment with the stilbene phytoalexins, resveratrol and pterostilbene. Camalexin has recently been involved in the induction of fungal apoptotic programmed cell death in $B$. cinerea (Shlezinger et al., 2011). The efficaciousness in vivo of some phytoalexins, namely the coumarin phytoalexin, scopoletin on the reduction of green mold symptoms caused by Penicillium digitatum on oranges was shown (Sanzani et al.,, 2014). In the same way, phenolic phytoalexins (resveratrol, scopoletin, scoparone and umbelliferone) were shown to significantly inhibit the growth of Penicillium expansum and patulin accumulation in apples. Beside their antifungal activity, phytoalexins possess some antibacterial activity. Rishitin for instance decreased the viability of cells of Erwinia atroseptica by around $100 \%$ at a dose of $360 \mu \mathrm{g} / \mathrm{L}$ (Lyon and Bayliss, 1975). Resveratrol also exerts some activity against numerous bacteria affecting humans: Chlamydia, Helicobacter, Staphylococcus,
Enterococcus, Pseudomonas and Neisseria. It is thus clear that phytoalexins exhibit toxicity across much of the biological spectrum, prokaryotic and eukaryotic.

In conclusion, phytoalexins are only one component of the complex mechanisms for disease resistance in plants. Studies on phytoalexins alone have contributed a great deal to plant biochemistry and molecular biology. Phytoalexin production and accumulation occur in healthy plant cells surrounding wounded or infected cells and are stimulated by alarm substances produced and released by the damaged cells and diffusing into the adjacent healthy cells. Phytoalexins are not produced during compatible biotrophic infections. Most phytoalexin elicitors are generally high molecular weight substances that are constituents of the fungal cell wall, such as glucans, chitosan, glycoproteins and polysaccharides. The elicitor molecules are released from the fungal cell wall by host plant enzymes. Most such elicitors are nonspecific, i.e., they are present in both compatible and incompatible races of the pathogen and induce phytoalexin accumulation irrespective of the plant cultivar. A few phytoalexin elicitors however are specific as the accumulation of phytoalexin they cause on certain compatible and incompatible cultivars parallels the phytoalexin accumulation caused by the pathogen races themselves. Some of the better studied phytoalexins include phaseollin in bean; pisatin in pea; glyceollin in soybean; alfalfa and clover; rishitin in potato; gossypol in cotton and capsidiol in pepper.

\section{References}

Alghisi P and Favaron F. 1995. Pectin-degrading enzymes and plant parasite interactions. Euro J Plant Pathol. 101: 365-375.

Anderson AJ. 1989. The biology of glycoproteins as elicitors. In: Plant-Microbe Interactions. 
Kosege T and Nester EW (Ed). McGrawHill, New York. 3.

Blein JP, Mitat ML and Ricci P. 1991. Responses of cultured tobacco cells to cryptogein, a proteinaceaus elicitor from Phytophthora cryptogea. Plant Physiol. 95: 486-491.

Cruickshank IA and Perrin DR. 1968. The isolation and partial characterisation of Monilicolin A, a polypeptide with phaseollin inducing activity from Monilinia fructicola. Life Sciences. 7: 449-458.

Cruickshank, IAM and Perrin, DR. 1960. Isolation of a phytoalexin from Pisum sativum L. Nature 187: 799-800.

Darvill AG and Albersheim P. 1984. Phytoalexins and their elicitors-A defence against microbial infection in plant. Ann Rev Plant Physiol. 35: 243-275.

Dixon RA, Lamb CJ. 1990. Molecular communication in interaction between plants and microbial pathogens. Ann. Rev. Plant Physiology and Plant Mol. Biol. 41: 339-367.

Harris JE and Dennis C. 1977. The effect of postinfectional potato tuber metabolites and surfactants on zoospores of Oomycetes. Physiol. Plant Pathol. 11: 163-169.

Joseph K. 1995. Phytoalexins, stress metabolism, and disease resistance in plants. Annu. Rev. Phytopathol.33:275-295.

Kodama O, Li WX, Tamogami S, Akatsuka T and Oryzalexin S. 1992. A novel stemarane-type diterpene rice phytoalexin. Biosci Biotech Biochem. 56: 1002-1003.

Lamb CJ, Lawton MA, Dron M and Dixon RA. 1989. Signals and transduction mechanisms for activation of plant defences against microbial attack. Cell. 56: 215- 224.

\section{How to cite this article:}

Roop Singh and Kuldeep Singh Chandrawat. 2017. Role of Phytoalexins in Plant Disease Resistance. Int.J.Curr.Microbiol.App.Sci. 6(1): 125-129.

doi: http://dx.doi.org/10.20546/ijcmas.2017.601.016
Lyon GD and Bayliss CE. 1975. The effect of rishitin on Erwinia carotovora var. atroseptica and other bacteria. Physiol. Plant Pathol. 6: 177-186.

Mansfield JW. 1999. Antimicrobial compounds and resistance: the role of phytoalexins and antianticipins. In: Mechanisms of Resistance to Plant Diseases. Slusarenko AJ, Fraser RSS and VanLoon LC (Ed). Kluwer, Amsterdam.

Mert-Turk F, Bennett MH, Glazebrook J, Mansfield J and Holub E. 1998. Biotic and abiotic elicitation of camalexin in Arabidopsis thaliana. 7th International Congress of Plant Pathology. Edinburgh, Scotland, UK.

Sanzani S, Schena L and Ippolito A. 2014. Effectiveness of phenolic compounds against citrus green mould. Molecules 19 : 12500-12508.

Shlezinger N, Minz A, Gur Y, Hatam I, Dagdas YF, Talbot NJ, Sharon A. 2011. Antiapoptoticmachinery protects the necrotrophic fungus Botrytis cinerea from host-induced apoptotic-like cell death during plant infection. PLoS Pathog. 7: e1002185.

Woods JA, Hafield JA, Pettit GR, Fox BW and McGown AT. 1995. The interaction with tubulin of a series of stilbenes based on combretastatin A-4. Br. J. Cancer. 71: 705-711.

Muller, K.O. and Borger, H. 1940. Experimentelle untersuchungen über die Phytophthora resistenz der Kartoffel. Arbeit. Biol. Reichsant Land Forstwirtsch. 23: 189-231. 